\title{
PENGARUH PENAMBAHAN BAWANG PUTIH TERHADAP KUALITAS TELUR ASIN
}

\author{
Anni Faridah ${ }^{1}$, Rahmi Holinesti ${ }^{1}$, Nina Kurnia ${ }^{2}$ \\ ${ }^{1}$ Dosen Fakultas Pariwisata dan Perhotelan, UNP \\ ${ }^{2}$ Alumni Program Studi Pendidikan Kesejahteraan Keluarga \\ email: faridah.anni@gmail.com
}

\begin{abstract}
Improved quality of salted egg conducted by creating a new variant, one of which with the addition of garlic. This research aims to analyze the effect of the addition of garlic as much as $0 \%, 15 \%, 30 \%$ and $45 \%$ of the quality colour, aroma, texture, and taste the salty eggs. Type of research is true experimental with completely randomized design method. Variables used are variable $X$ (garlic) and the variable $Y$ (quality of salted eggs). The data used was obtained directly from 30 semi trained panelists. Data analyzed by using ANAVA, if different real continued with Test Duncan. The results showed there is the influence of the addition of garlic to the quality of the scent is not fishy, garlic aroma, taste salty, savory taste, aroma and taste of the hedonic. There is no real influence on quality of the color orange, white eggs on a chewy texture, granulated texture in egg yolk, hedonic color and texture of salted egg hedonic. The quality of salted eggs best use garlic as much as $45 \%$ (X3).
\end{abstract}

Keywords: Garlic, Quality of Organoleptic, Salted Eggs.

\section{PENDAHULUAN}

Telur asin merupakan makanan yang cocok dijadikan oleh-oleh para wisatawan karena selain praktis juga mengandung gizi tinggi. Sumatera Barat bukanlah sentral produksi ataupun penjualan telur asin, namun produksi telur itik di Sumatera Barat tergolong banyak. Produksi telur itik di Sumatera Barat mencapai 6.809 ton pada tahun 2015 dan relatif meningkat setiap tahunnya (Direktorat Jendral Peternakan dan Kesehatan Hewan). Telur itik merupakan bahan pangan yang mudah rusak karena banyak mengandung nutrisi yang dibutuhkan untuk pertumbuhan mikroorganisme. Oleh sebab itu telur itik diolah menjadi telur asin. Telur itik memiliki kandungan gizi 189kal Energi, 13.10kal Protein, 14.30kal Lemak, 0.80kal Karbohidrat, 56.00mg Kalsium, 175mg Fosfor, 3.00mg Besi, 12.30mcg Vit A, 0.18mg Vit B1 (DKBM Indonesia, 2010).

Telur asin yang ada dipasaran adalah telur asin dengan rasa original. Berdasarkan wawancara bersama \pm 45 orang yang peneliti lakukan pada Juli 2016 di Gedung Jurusan Ilmu Kesejahteraan Keluarga UNP, telur asin original beraroma amis sehingga kurang disukai, dianggap kurang variatif dan kurang mengikuti selera konsumen. Oleh sebab itu perlu dilakukan 
inovasi dengan penambahan bahan yang beraroma tajam, seperti bawang putih.

Bawang putih tergolong dalam keluarga Liliiaceae yang paling berbau tajam dan pedas (Hermes, 2001). Bawang putih memiliki kandungan gizi 95kal Energi, 4.50g Protein, 0.20g Lemak, 23.10g Karbohidrat, 42.00mg Kalsium, 134mg Fosfor, 1.00mg Besi, 15.0mg Vit C, $0.22 \mathrm{mg}$ Vit B-1 (DKBM Indonesia, 2010). Bawang putih memiliki komponen sulfur yang lebih tinggi dibandingkan dengan spesies Allium lainnya. Komponen sulfur inilah yang memberikan bau khas bawang putih (Londhe, 2011). Bawang putih berpotensi sebagai antimikroba. Kemampuannya menghambat pertumbuhan mikrobia sangat luas, mencakup virus, bakteri, protozoa, dan jamur (Nok et. al., 1996; Zhang, 1999; Ohta et. al., 1999; Pizorno et. al., 2000; Yin et. al., 2002).

Bawang putih secara umum banyak dimanfaatkan sebagai bumbu penyedap masakan maupun sebagai bahan baku obatobatan bagi masyarakat (Susanti, 2016:1). Adanya sifat antioksidan dan antimikroba pada bawang putih maka dapat berfungsi sebagai bahan pengawet alami. Penggunaan bawang putih dalam pembuatan telur asin merupakan upaya pengawetan berlapis.

Penambahan bawang putih pada pembuatan telur asin merupakan upaya penganekaragaman cita rasa sehingga berkemungkinan bertambahnya peminat telur asin dan bertambah juga peluang usaha pedagang telur asin. Selain itu juga untuk mempertahankan serta meningkatkan minat konsumen terhadap telur asin baik bagi wisatawan lokal maupun wisatawan asing, maka perlu adanya pengkajian, peningkatan mutu (warna, aroma, tekstur, dan rasa) dari makanan bergizi tersebut. Untuk hal ini penulis tertarik melakukan penelitian dengan menambahkan bawang putih yang mudah didapatkan dalam pembuatan telur asin.

Penelitian ini dilakukan dengan tujuan menganalisis pengaruh dan perbedaan pengaruh penambahan bawang putih sebanyak $15 \%, 30 \%$, dan $45 \%$ dari jumlah bahan yang digunakan terhadap kualitas warna, aroma, tekstur, dan rasa telur asin.

\section{METODE PENELITIAN}

Penelitian yang dilakukan adalah eksperimen murni (true eksperimen) dengan dua variabel yaitu variabel $X$ (penambahan bawang putih) dan variabel Y (kualitas telur asin). Jadi rancangan yang digunakan yaitu rancangan acak lengkap (RAL), yang terdiri dari 4 perlakuan (penambahan bawang putih 0\%, 15\%, 30\% dan $45 \%$ dari jumlah bahan yang digunakan) dan melibatkan 30 orang panelis. Penelitian ini dilaksanakan di Workshop Tata Boga, Jurusan Ilmu Kesejahteraan Keluarga, Fakultas 
Pariwisata dan Perhotelan, Universitas sebanyak 3 kali pengulangan.

Negeri Padang pada bulan Desember 2016

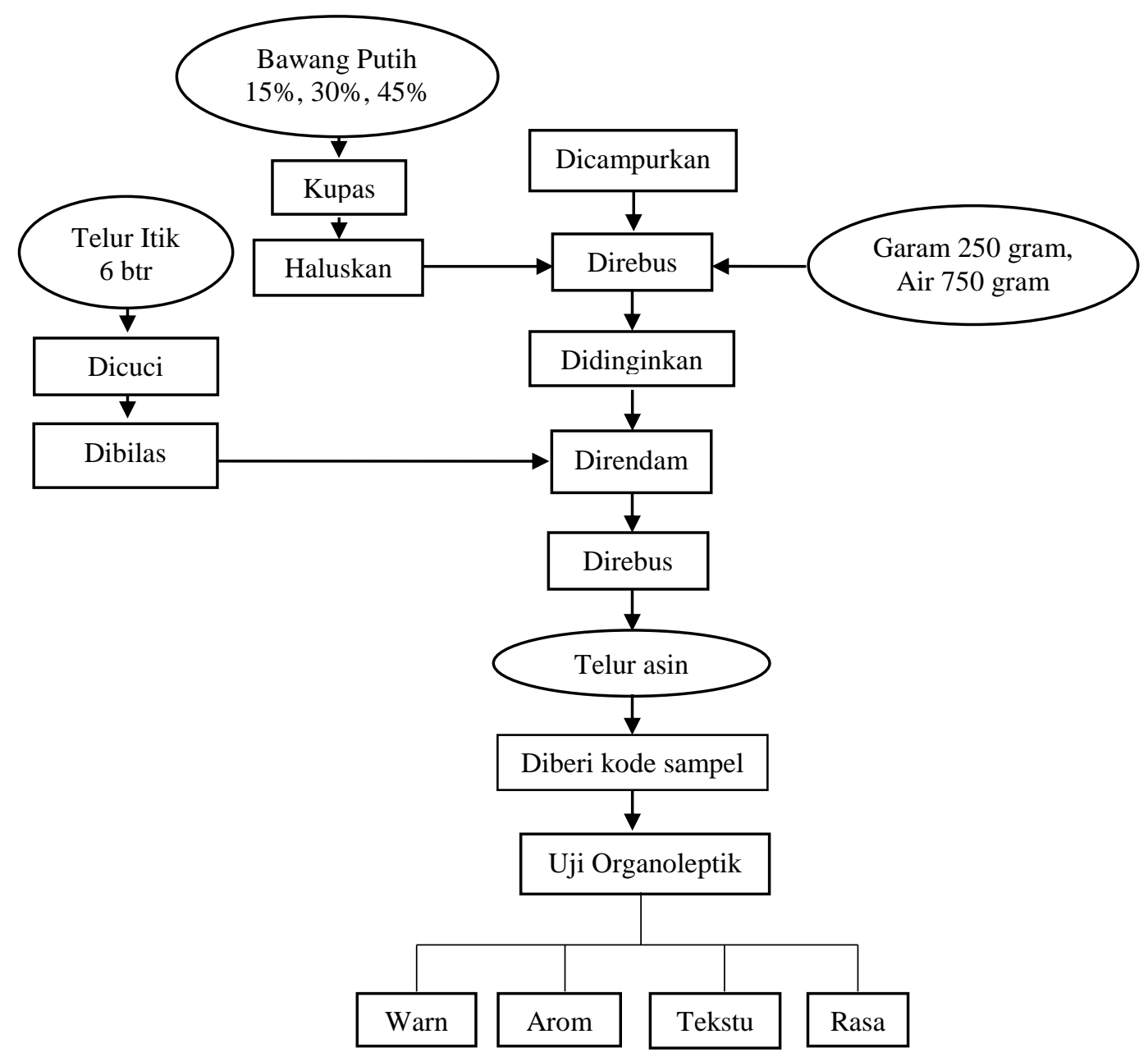

Gambar 1. Diagram Alir Pembuatan Telur Asin

Bahan baku dalam pembuatan telur asin yang digunakan berkualitas baik serta penimbangan bahan yang tepat ukuran. Adapun bahan-bahan dalam pembuatan telur asin yaitu: telur itik, bawang putih, garam, dan air. Sedangkan alat yang digunakan adalah alat untuk memasak. Tahap pengolahan telur asin dilaksanakan sesuai langkah-langkah kerja yang telah ditentukan agar tidak terjadi kesalahan dalam tahap ini. Adapun diagram alir proses pembuatan hingga tahap penilaian telur asin seperti pada Gambar 1.

Data yang telah diperoleh, ditabulasi dalam bentuk tabel dan dihitung rata-rata setiap perlakuan dan kemuadian dianalisa dengan analisa varian (ANAVA), jika berbeda nyata dilanjutkan dengan uji lanjut Duncan. 


\section{HASIL DAN PEMBAHASAN}

Berdasarkan uji organoleptik yang telah dilakukan terhadap kualitas telur asin yang meliputi kualitas warna (orange pada bagian kunig telur), aroma (tidak amis dan harum khas bawang putih), tekstur (kenyal pada putih telur dan masir pada kuning telur), rasa (asin dan rasa gurih khas bawang putih) maka diperoleh rata-rata dari nilai masing masing kualitas atau hasil penelitian seperti pada gambar 2 dan gambar 3.

Hasil analisa varian dari kualitas uji organoleptik untuk kualitas: aroma (tidak amis dan harum khas bawang putih) serta hedonik aroma telur asin, rasa (asin dan rasa gurih khas bawang putih) serta hedonik kualitas rasa telur asin berbeda nyata, sehingga perlu dilakukan uji lanjut Duncan yang dapat dilihat pada Tabel 1 .

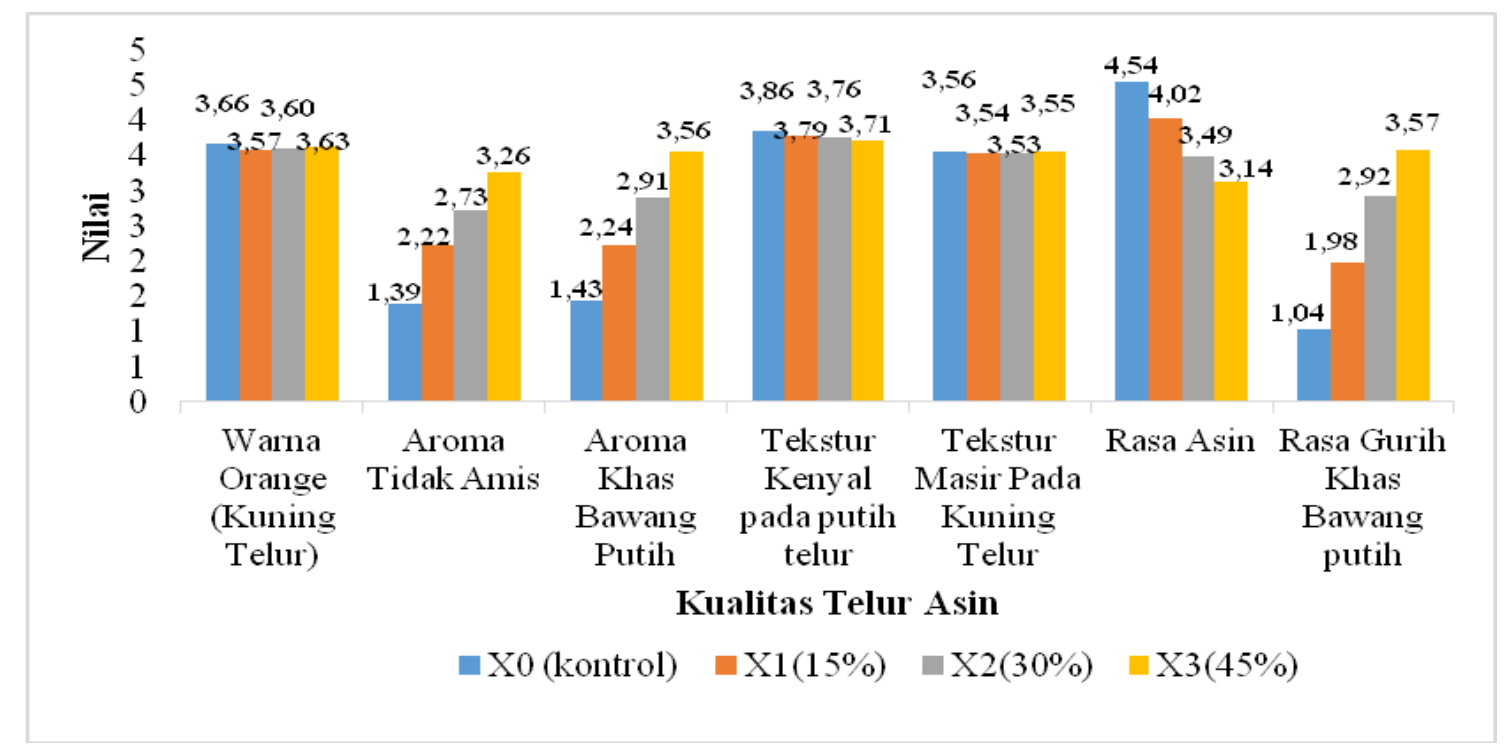

Gambar 2. Uji Jenjang Kualitas Telur Asin dengan Penambahan Bawang Putih

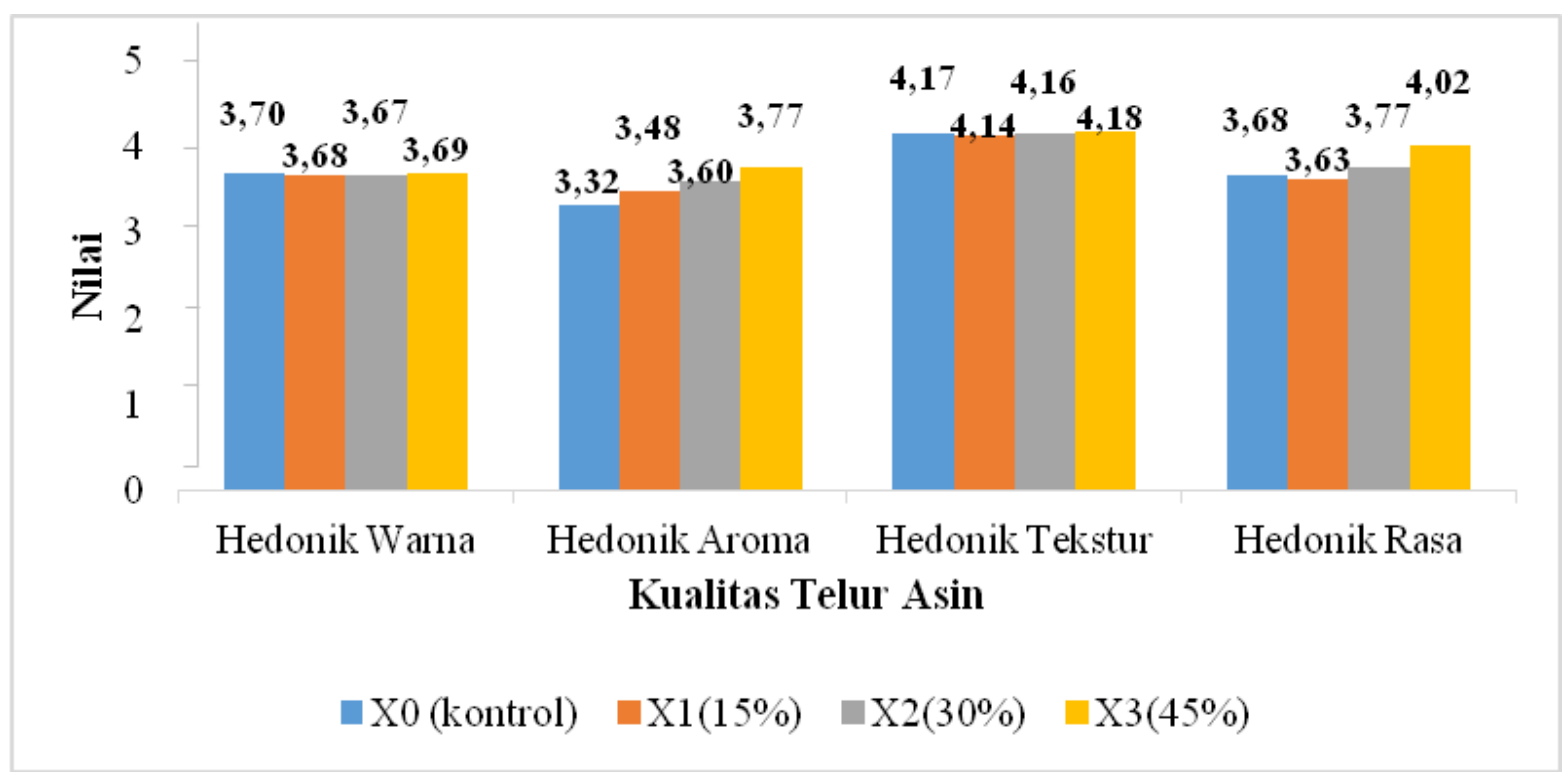

Gambar 3. Uji Hedonik Kualitas Telur Asin dengan Penambahan Bawang Putih 
Tabel 1. Hasil Uji Lanjut Duncan Kualitas Telur Asin

\begin{tabular}{|c|c|c|c|c|c|}
\hline \multirow{2}{*}{ No } & \multirow{2}{*}{ Kualitas } & \multicolumn{4}{|c|}{ Nilai Sampel } \\
\cline { 3 - 6 } & & $\mathrm{X}_{0}$ & $\mathrm{X}_{1}$ & $\mathrm{X}_{2}$ & $\mathrm{X}_{3}$ \\
\hline 1 & Aroma tidak amis & $1,39 \mathrm{a}$ & $2,22 \mathrm{~b}$ & $2,73 \mathrm{c}$ & $3.26 \mathrm{~d}$ \\
\hline 2 & Aroma harum khas bawang putih & $1.43 \mathrm{a}$ & $2.24 \mathrm{~b}$ & $2.91 \mathrm{c}$ & $3.56 \mathrm{~d}$ \\
\hline 3 & Hedonik Aroma telur asin & $3,32 \mathrm{a}$ & $3,48 \mathrm{a}$ & $3,60 \mathrm{a}$ & $3,77 \mathrm{~b}$ \\
\hline 4 & Rasa asin & $4,54 \mathrm{~d}$ & $4,02 \mathrm{c}$ & $3,49 \mathrm{~b}$ & $3,14 \mathrm{a}$ \\
\hline 5 & Rasa gurih khas bawang putih & $1,04 \mathrm{a}$ & $1,98 \mathrm{~b}$ & $2,92 \mathrm{c}$ & $3.57 \mathrm{~d}$ \\
\hline 6 & Hedonik rasa telur asin & $3.68 \mathrm{a}$ & $3,63 \mathrm{a}$ & $3.77 \mathrm{~b}$ & $4.02 \mathrm{~b}$ \\
\hline
\end{tabular}

Keterangan: Huruf yang berbeda dibelakang angka menyatakan perbedaan yang nyata.

Hasil kualitas telur asin yang meliputi kualitas warna, aroma, tekstur, dan rasa. Berikut ini akan dibahas kualitas Telur asin berdasarkan masing-masing indikator:

\section{Pengaruh Kualitas Warna Telur Asin} dengan Penambahan Bawang Putih $(0 \%, 15 \%, 30 \%$, dan $45 \%)$

Hasil penelitian menyatakan $\mathrm{Ha}$ ditolak yang artinya tidak terdapat perbedaan yang nyata terhadap kualitas warna orange dan hedonik warna orange pada bagian kuning telur asin dengan penambahan bawang putih.

Kehilangan air dari telur menyebabkan perubahan warna pada kuning telur. Konsentrasi garam menyebabkan kadar air telur menurun sehingga adanya perubahan warna pada kuning telur. Sesuai dengan pernyataan Lai et. al. dalam Oktaviani dkk
(2012:109) bahwa warna kuning telur sebelum mengalami proses pengasinan adalah kuning, warna akan berubah menjadi kuning kecoklatan, cokelat tua, orange atau kuning cerah setelah melalui proses pengasinan. Dengan demikian pengasinan menyebabkan kadar air telur menurun sehingga warna orange pada kuning telur semakin pekat. Tidak adanya perbedaan yang nyata terhadap warna antara masing-masing perlakuan diduga karena penggunaan garam dengan jumlah yang sama, dan waktu perendaman yang sama pada saat proses perendaman, sehingga tidak mempengaruhi penampakan warna kuning telur asin.

Kadar warna orange pada bagian kuning telur asin juga tergantung pada kualitas awal telur itik yang digunakan. Dengan penambahan bawang putih pada pembuatan telur asin, walaupun nilai 
kontrol tinggi bukan berarti kualitas warna menurun. Hal tersebut tidak dapat dapat dibuktikan.

\section{Pengaruh Kualitas Aroma telur Asin} dengan Penambahan Bawang Putih $(0 \%, 15 \%, 30 \%$, dan $45 \%)$

Hasil analisis ANAVA menyatakan $\mathrm{Ha}$ diterima yang artinya terdapat pengaruh yang nyata terhadap kualitas aroma tidak amis, aroma harum khas bawang putih dan hedonik aroma pada telur asin dengan penambahan bawang putih.

Aroma amis pada telur asin merupakan sifat dari telur itik sendiri. Adanya perbedaan yang nyata terhadap aroma tidak amis antara masing-masing perlakuan diduga karena penggunakan variable yang berbeda dalam jumlah penggunaan bawang putih, sehingga semakin banyak penambahan bawang putih maka semakin berkurang aroma amis pada telur asin. Bawang putih memiliki karakteristik aroma tajam. Dalam penggunaanya bawang putih dihaluskan dan direbus bersama cairan perendam sehingga aroma pada bawang putih semakin tajam.

Moehyi (1992:99) menyatakan "Timbulnya aroma makanan disebabkan oleh terbentuknya senyawa yang mudah menguap”. Air yang terkandung dalam bawang putih akan menguap selama proses pemasakan yang dilakukan.

Adanya perbedaan yang nyata terhadap aroma harum khas bawang putih antara masing-masing perlakuan diduga karena bawang putih yang memiliki karakteristik aroma tajam. Pada penelitian ini, bawang putih dihaluskan dan direbus bersama cairan perendam sehingga aroma pada bawang menguap selama proses pemasakan hingga perendaman dalam wadah tertutup sehingga diyakini aromanya akan masuk kedalam telur itik melalui pori-pori telur. Setiap perlakuan akan menghasilkan aroma bawang putih yang berbeda, karena menggunakan jumlah bawang putih yang berbeda-beda.

\section{Pengaruh Kualitas Tekstur Telur} Asin dengan Penambahan Bawang Putih (0\%, 15\%, 30\%, dan 45\%)

Hasil penelitian menyatakan $\mathrm{Ha}$ ditolak yang artinya tidak terdapat pengaruh yang nyata terhadap kualitas tekstur kenyal (putih telur), tekstur masir (kuing telur) dan hedonik tekstur pada telur asin dengan penambahan bawang putih.

Garam dan air yang masuk ke dalam putih telur atau disebut proses difusi akan mempengaruhi kekenyalan dari putih telur, hal ini sesuai dengan pendapat Budiman dkk (2012:225) 
bahwa tingkat kekenyalan yang cenderung semakin meningkat disebabkan karena pengaruh kadar air, kadar air yang sedikit akan menghasilkan tekstur yang kenyal. Selain itu, penyebab kekenyalan menurut Hidayat (2007) bahwa semakin tinggi suhu dan lama waktu pemasakan, maka protein telur terkoagulasi semakin cepat berubah bentuk menjadi gel dan lama kelamaan berubah menjadi padat dan kenyal.

Tidak adanya perbedaan yang nyata terhadap tekstur kenyal antara masing-masing perlakuan diduga karena penurunan kadar air telur asin relatif sama, sehingga tekstur putih telur asin yang dihasilkan cenderung sama.

Kadar air yang rendah pada lemak yang tinggi membuat kuning telur lebih masir. Menurut Chi dan Tseng (1998) tekstur masir disebabkan oleh membesarnya granula yang ada dalam kuning telur. Membesarnya granula pada kuning telur dipengaruhi oleh dua faktor yaitu kadar garam dan kadar air. Lebih lanjut Utomo (2006:23) menjelaskan bahwa kadar garam dan air pada kuning telur asin menyebabkan persentase kemasiran kuning telur asin tinggi, jadi semakin tua umur telur yang diasin semakin tinggi persentase kemasiran".

Tidak adanya perbedaan yang nyata terhadap tekstur masir antara masing-masing perlakuan diduga karena penggunaan garam, air, dan waktu perendaman yang sama pada setiap perlakuan, sehingga tekstur masir telur asin yang dihasilkan cenderung sama.

\section{Pengaruh Kualitas Rasa Telur Asin dengan Penambahan Bawang Putih $(0 \%, 15 \%, 30 \%$ dan $45 \%)$}

Hasil analisis ANAVA menyatakan $\mathrm{Ha}$ diterima yang artinya terdapat pengaruh penambahan bawang putih pada pembuatan telur asin terhadap kualitas rasa asin, rasa gurih khas bawang putih dan hedonik rasa. Hasil penelitian menunjukkan bahwa semakin tinggi penambahan bawang putih pada proses pengasinan telur, maka kadar garam atau rasa asin pada telur asin semakin menurun. Hal ini diduga adanya pengaruh bawang putih yang ditambahkan pada proses pembuatan telur asin terhadap kepekatan larutan garam. Hal ini sesuai dengan hasil penelitian lidya (2013), pencampuran antara vitamin $\mathrm{C}$ dengan garam beriodium menyebabkan terbentuknya iodium bebas. Pada bawang putih diketahui memiliki kandungan vitamin $\mathrm{C}$ yang cukup tinggi yaitu $15.0 \mathrm{mg}$ per 100 gram bahan. Semakin banyak penggunaan bawang putih berarti semakin tinggi vitamin $\mathrm{C}$ yang mengikat garam sehingga dapat 
dipahami apabila semakin banyak penambahan bawang putih, maka kadar garam atau rasa asin dalam telur asin semakin menurun.

Menurut Erryga dan Puji (2010:196) bawang putih dapat meningkatkan rasa gurih pada makanan. Salah satu pembentuk rasa gurih adalah protein. Pada bawang putih diketahui memiliki kandungan protein $4.50 \mathrm{mg}$ per 100 gram bahan. Jadi, kemungkinan semakin banyak penggunaan bawang putih berarti semakin meningkat kandungan proteinnya dan akan meningkat pula rasa gurihnya.

\section{KESIMPULAN DAN SARAN}

Kualitas telur asin dengan penambahan bawang putih sebanyak $0 \%$, $15 \%, 30 \%$ dan $45 \%$ terhadap kualitas warna orange pada bagian kuning telur, tekstur kenyal pada bagian putih telur, tekstur masir pada bagian kuning telur dan hedonik warna pada bagian kuning telur serta hedonik tekstur telur asin tidak terdapat pengaruh yang nyata. Sedangkan untuk kualitas aroma tidak amis, aroma harum khas bawang putih, rasa asin, dan rasa gurih khas bawang putih dan hedonik aroma telur asin serta hedonik rasa telur asin, terdapat pengaruh yang nyata. Kualitas telur asin yang terbaik adalah penambahan bawang putih sebanyak $45 \%$ $\left(\mathrm{X}_{3}\right)$ dengan nilai kualitas warna orange

pada bagian kuning telur 3.63; hedonik warna orange pada bagian kuning telur 3.69; aroma tidak amis 3.26; aroma harum khas bawang putih 3.56; hedonik aroma telur asin 3.77 ; tekstur kenyal pada bagian putih telur 3.79; tekstur masir pada bagian kuning telur 3.55; hedonik tekstur telur asin 4.18; rasa asin 3,14; rasa gurih khas bawang putih 3.57; dan hedonik rasa telur asin 4.02.

Perendaman telur itik dilakukan selama 10 hari menghasilkan telur asin bertekstur masir tidak sampai ke bagian tengah. Kemungkinan untuk hasil tekstur masir hingga ke bagian tengah dapat dicapai dengan waktu perendaman lebih yaitu kisaran 15 s/d 20 hari. Telur asin yang telah melalui proses perebusan sebaiknya segera diangkat dan direndam dengan air dinginuntuk mempermudah pengupasan cangkang. Semoga dengan adanya penelitian ini dapat meningkatkan penganekaragaman telur asin yang bervariasi dengan memanfaatkan tumbuhan herbal dan dapat menjadi acuan untuk penelitian yang akan mendatang. 


\section{DAFTAR PUSTAKA}

Budi Utomo. 2006. "Pengaruh Umur Telur Terhadap Kualitas Kemasiran Telur Asin Yang Diasin Selama 14 Hari”, Skripsi, Bogor, Fakultas Peternakan Institut Pertanian Bogor.

Chi, S. P. and K. H. Tseng. 1998. Physicochemical properties of salted picled yolk from duck and chicken eggs. J. Food Sci. \& Technology, National Taiwan Univ.

Direktorat Jenderal Peternakan Dan Kesehatan Hewan. 2015. Statistik Peternakan dan Kesehatan Hewan 2015. Jakarta: Direktorat Jenderal Peternakan dan Kesehatan Hewan Kementerian Pertanian RI.

Hermes, 2001. Ensiklopedia Juice Buah dan Sayur untuk Penyembuhan (Terjemahan dari: Heinerman's Encyclopedia of Healing Juice,Penulis : John Heinerman). Jakarta: Pustaka Delaprasta.

Hidayat, A. 2007. "Pengaruh Perbedaan Cara dan Lama Pemasakan Telur Asin Terhadap Sifat Organoleptik", Skripsi, Purwokerto, Fakultas Peternakan Universitas Jenderal Soedirman.

Lidya, Sarah. 2013. Uji Yodium pada Amilum (online), (http://lidyasarah.blogspot.co.id/201 4/11/artikel-uji-yodium.html, Diakses Pada 05 Mei 2017).

Londhe V.P. et al. 2011. Role Of Garlic (Allium Sativum) In Various Diseases: An Overview. Journal of Pharmaceutical Research And Opinion, (online), Vol. 1: 4. (Https://Www.Researchgate.Net/Pu blication/233379240, Diakses Pada 31 Agustus 2016).
Moehyi, S. 1992. Makanan Institusi dan Jasa Boga. Jakarta: Bhratara Niagara Media.

Nok, A.J., S. Williams, and P.C. Onyenekwe. $1996 . \quad$ "Allium sativum-induced death of African trypanosomes". Parasitology Research, 82: 634-637

Oktaviani, H., N. Kaniadadan N. R. Utami. 2012. "Pengaruh Pengasinan Terhadap Kandungan Zat Gizi Telur Bebek Yang Diberi Limbah Udang”. Jurnal, Unnes.

Suyatno. 2010. "Daftar Kebutuhan Bahan Makanan Indonesiahttp:// suyatno.blog.undip.ac.id, Diakses pada 01 Oktober 2014.

Vevi, Susanti. 2016. "Serangan Hama Spodoptera exigua Hubner (Lepidoptera: Noctuidae) Pada Pertanaman Bawang Di Sumatera Barat". Diploma thesis, Universitas Andalas. 